\title{
8 \\ Gadejuristen [The Street Lawyers]: Offering Legal Aid to Socially Marginalised People
}

\section{Stine Piilgaard Porner Nielsen and Ole Hammerslev}

\section{Introduction}

The streets of Copenhagen in the area behind the Central Station constitute the outdoor office of the Gadejuristen. Twice a week members of staff and volunteers bike around the streets of Copenhagen, transporting themselves and their supplies on a Christiania bike. The bike is parked; the staff open the bike cover, take out coffee, hot chocolate, disposable cups and biscuits. Packs of cigarettes and lighters are distributed among the staff to hand out on request and soon the first potential clients gather around the bike. Informal chat, the pouring of hot drinks and smoke from cigarettes fill the air - all part of a normal evening in the outdoor office of the Gadejuristen (field notes).

\section{S.P.P. Nielsen $(\bowtie)$}

Department of Law, University of Southern Denmark, Odense M, Denmark

O. Hammerslev

Department of Law, University of Southern Denmark, Odense M, Denmark Department of Criminology and Sociology of Law, University of Oslo, Oslo, Norway 
The primary purpose of the welfare state is to compensate for events that may lead to the exclusion of citizens by offering support and help to those who are entitled to it (Appel Nissen 2007, p. 62; Bauman 2004, p. 66). However, a number of legal aid studies show that administrative deficiencies in the welfare system, and socially marginalised people's lack of knowledge of their rights to treatment or social benefits, may prevent their accessing welfare rights if they are not supported in the process (Lied 2011; Gadejuristen 2011). This chapter focuses on the organisation Gadejuristen (The Street Lawyers), which provides such legal aid to people who are among the most marginalised and most lacking in resources in Denmark, namely drug users, street sex workers, and homeless persons. Gadejuristen is an independent non-profit organisation established in 1999 as a response to what the founder, Nanna Gotfredsen, saw as inadequate treatment of socially marginalised people by public bodies such as the police and the welfare system. In an interview, Gotfredsen said:

'Some people were denied their rights - for instance, to treatment for drug use, or were not getting the benefit they were entitled to, because of maladministration. Having a lawyer to represent them increased their access to the rights they were entitled to, and this experience led to the establishment of the organisation and the practice of street lawyering.' (Our translation)

Gadejuristen started in Copenhagen where it still has its office and does most of its work but it also offers legal aid in other Danish cities. The aim of the organisation is to provide legal aid to the socially marginalised, and improve the daily lives of such people through policy work. To ensure these aims in the Danish welfare society the organisation focuses on two areas: at the individual level, it provides legal aid for the specific target group, partly through outreach legal aid, and, at the societal level, its work is policy oriented, and it seeks through knowledge dissemination, lobbyism, and education to improve the lives of their target group. In the organisation's view, the two levels are intertwined and equally important, as both contribute to improving the lives of the target group. ${ }^{1}$

Gadejuristen differs from other legal aid institutions in Denmark (see Chap. 5) in a number of ways: the organisation focuses on a specific 
target group, provides outreach legal aid, and assists its users throughout the legal process in terms of advice, representation, and in practical matters such as providing bus tickets, mobile phones, etc. ${ }^{2}$ It also offers supplementary social and economic support to the target group and works to influence the political landscape. Against the backdrop of traditional understandings of legal aid, as defined in classic Nordic studies (see Chap. 1), the present chapter demonstrates how Gadejuristen interprets and delivers legal aid, and how the development of the Danish welfare state impacts the organisation's work. The case of Gadejuristen also illustrates how legal aid, for certain groups in society, is intertwined with social work, policy work and knowledge dissemination.

The only research existing on street lawyering in Denmark is Camilla Lied's Norwegian Gatejurister. Oppsøkende rettshjelp til folk med rusrelaterte problemer [The Street Lawyers. Outreach legal aid to people with drug related problems] of 2013, which is based on her University of Oslo doctoral thesis (2011). This compares Gadejuristen in Copenhagen with Gatejuristen in Oslo and examines the methods used in street lawyering, how Gatejuristen in Oslo and Gadejuristen in Copenhagen work with their target group, users, and public authorities, and how the users experience contact with the organisations. In 2011, a report was published by Copenhagen Gadejuristen, describing in detail the work of the organisation at the time.

Based on fieldwork and interviews with previous and present street lawyers, this chapter examines the work of Gadejuristen in the context of the Danish welfare state. The chapter has three parts and a conclusion. The first part outlines the organisation of Gadejuristen, focusing on the staff, the funding situation, and the number and type of cases dealt with. The second part examines the aid provided by Gadejuristen by investigating how the work on the streets is conducted, and how Gadejuristen navigate in the Welfare State and become a kind of mediator between their target group and the welfare state. The third part focuses on the effect of their political and societal approaches to socially marginalised people and how the organisation has adopted a street lawyer method of working. The chapter sums up its findings in a conclusion. 


\section{The Organisation of Gadejuristen}

\section{Staff, Funding, and Type of Cases}

Gadejuristen represents socially marginalised people because of its founder's experience of street lawyering in the streets of Copenhagen in the 1990s. The recognition that socially marginalised people faced difficulties in accessing their welfare rights, and that legal representation remedied this, led to the establishment of the organisation in 1999 and the formulation of its objective: to improve the lives of the target group. The target group was defined as those with nowhere else to go, and who needed help the most: drug users, street sex workers, and homeless persons. This group typically lead chaotic lives, as a result of substance abuse, lack of housing, and/or the lack of networks and resources to navigate in the welfare system. Gadejuristen works to increase the target group's chances of inclusion in the welfare state by presenting their cases and supporting them in everyday life and in meetings with welfare state representatives, such as social workers and health staff.

When Gadejuristen was founded, it only had one full-time project leader. Since then, the number of people working with Gadejuristen has gradually increased, as has the number of volunteers. Today, the organisation has five lawyers and one social worker employed full-time and one law student part-time. The number of employees depends on external funding, which is related to the projects carried out by the organisation. Over the years, the organisation has initiated various projects catering for the target group, including The Parents' Network, in 2007, and The Street Level Project, in 2002. The Parents' Network enables parents with current or past drug use to access counselling and engage in informal social meetings, whereas The Street Level Network is an outreach project facilitated by volunteers who provide an alternative resource network for drug users. The support offered by the volunteers is tailored to the drug users' needs and demands, and is thus a flexible way of addressing the problems of the target group. ${ }^{3}$ The two projects both provide a framework of support for the target group but differ in that the latter is directed 
to the entire target group whereas the former is targeted at parents. Between 25 and 40 volunteers work in the organisation-mostly law students but other professions, such as nurses and psychologists are also represented. The diversity in professional background is necessary to accommodate the complex problems of the users: nurses and psychologists may better understand the consequences of withdrawal symptoms and how to address them, whereas volunteers with a legal background are trained to identify problems that are of a legal nature, enabling them to advocate for the rights of the users. The organisation relies on the volunteers' work to be able to handle the increasing number of users and support them in their dealings with the social system. The different professional backgrounds of the staff and volunteers mirror the forms of aid Gadejuristen provides, and the complex needs of the target group. If the target group is to get the help they need, legal expertise must be supplemented by knowledge of the medical and psychological options available. Because multiple factors are often intertwined in the target group's problems, support needs to combine a number of areas of professional expertise, for example, knowledge about possible mental and physical treatment, knowledge about the workings of the welfare system, and knowledge about the law. Though the volunteers and staff have different professional backgrounds and, thus, also focus on different areas, it is the law that is central in the work of Gadejuristen, as the law is used as a tool to access the welfare system, for example, by pointing to unlawful administrative processes and identifying the rights of users. By applying the law and displaying detailed knowledge of how the welfare system functions, the organisation positions itself as a representative of the users.

Most legal aid institutions in Denmark receive money from the legal aid fund of the Department of Civil Affairs (Civilstyrelsen 2015). This is not the case, however, with Gadejuristen, which finances projects in various ways, mostly through fundraising, donations, and access to funds through cooperation with public authorities. ${ }^{4}$ The organisation's outreach legal aid work, for example, is funded by the special fund for social areas, ${ }^{5}$ and the Parents' Network, mentioned above, is funded by the so-called Tips and Lotto Fund, which earmarks funding for social purposes. ${ }^{6}$ 


\section{Gadejuristen Cases}

A report published by Gadejuristen indicates a steady rise in users, from 10 in 2005 to 400 in 2010, and argues that there is a continuing need for the support offered by the organisation (Gadejuristen 2011, p. 27). The organisation has existed since 1999 but between 2005 and 2010 the numbers of users dramatically increased, which indicates that users seek out the support of Gadejuristen in order to navigate in the welfare system (Fig. 8.1).

Typical cases dealt with by Gadejuristen are to do with financial issues, and problems related to housing and homelessness, the labour market, drug substitution, and in-patient treatment (ibid., p. 10). Gadejuristen cases vary but a feature they often have in common is that different legal areas of expertise are involved at the same time, such as benefit rights, or rights to medical treatment. This is an indication of the complexity of the problems of the target group: they involve multiple legal areas and interrelated social problems, e.g., homelessness, drug use, and mental health issues. In order to support the target group, Gadejuristen thus needs to have comprehensive expertise in fields other than the legal, and in-depth knowledge of the lives of the target group, including familiarity with areas such as drug use and mental illness. Kristian Andenæs refers to this wide-ranging expertise as a professional requirement beyond legal professionalism, which is a necessary part of the street lawyer method

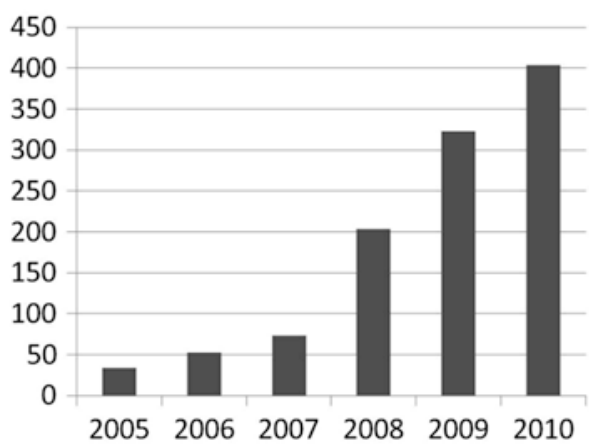

Fig. 8.1 Number of new users per year (Gadejuristen 2011, p. 27) 
(ibid., p. 21). This is elaborated further in the section on 'The Street Lawyer Method' below.

The increase in users, numbers of staff, and volunteers makes the organisation more visible on the streets, more available to potential users, and shows that there is an increasing need for the help provided by Gadejuristen. The complexity of the users' problems calls for detailed knowledge of various fields, and a professional understanding of how to navigate in these fields in order to ensure that the target group's needs are met. The following example elucidates how a detailed knowledge of legal administration and of rights to medical treatment enables Gadejuristen to act on behalf of the users: a man applied for in-patient treatment, i.e., treatment where the patient checks into the facility and remains there for the entire programme. He argued that if he did not have the treatment he would most likely die of his drug use. Gadejuristen helped him apply and waited for a ruling on the matter. When the letter arrived, it simply said: 'Decision: You cannot receive inpatient treatment.' Gadejuristen then contacted the responsible social worker and argued that the decision could only be interpreted as a ruling, and, as such, should be followed by the reason for the ruling and advice on how to appeal the ruling. Gadejuristen then helped formulate the appeal and based on the appeal the ruling was amended and the user was granted in-patient treatment (Gadejuristen 2011, p. 69).

The fact that Gadejuristen finances its work and projects by donations and fundraising means it has greater flexibility, and can go beyond traditional legal aid in a way that would not be possible if it had to conform to normal legal aid funds.

\section{The Work of Gadejuristen}

As mentioned in the introduction to this book, legal aid studies have shown that the visibility and accessibility of legal aid providers are important in establishing contact with and providing support to socially marginalised groups. From the beginning, Gadejuristen has been aware that it needs to create awareness of its services among the target group. Therefore, every Tuesday and Friday, Gadejuristen follows a specific route in the 
streets of Copenhagen with its Christiania bike which is a cargo bike with a large box in the front of the bike, loaded with coffee, snacks, and other goods for the target group. The route is in Vesterbro, where there are many socially marginalised people_-as this is where shelters and facilities for drug users are available. Gadejuristen typically goes from its office to the hostel for homeless men 'Mændenes Hjem' in Istedgade, and then to Cafeen, which is a drop-in centre close to the drug use facilities. They stop where the target group and potential clients are able to drop by for a chat and a cup of coffee, served from the lid of the Christiana box, which functions as a table, or have a cigarette or get condoms and clean needles for intravenous drug use. With these basic items available on the street, an informal chat often begins around the bike. Gadejuristen staff and volunteers greet people by name, sometimes they get hugs which indicates familiarity and trust (field notes). The informal relationship between Gadejuristen and the people dropping by opens the way to dialogue about everyday life and its problems. One worker points out the difference between calling in at other legal aid offices, and talking to someone from Gadejuristen:

'The precondition to drop by there [at the traditional legal aid office] is that you are aware that you are suffering from something illegal, but then one needs to know one's rights or at least have an idea of them. And our users haven't got that ... That [creating the awareness] is what happens in the encounters when we are having a cup of coffee.' (Our translation)

These informal talks enable Gadejuristen to systematically identify potential legal problems, which the target group may not be aware of, and so they are important steps towards providing users with the support they need. These informal talks and bike trips in the streets of Vesterbro go beyond traditional legal aid and are referred to as extended legal aid. Extended legal aid is a necessity due to the complexity of the target group's way of life and legal problems. It encompasses such things as informality, practical help in the form of covering expenses and providing cell phones, and the extra professional insights provided by the many volunteers and the staff. 
As shown in the example above, Gadejuristen makes use of informal talks but also draws on traditional legal practice, as the organisation aims to serve the users' interests and handle their cases from beginning to end. In the case of in-patient treatment, Gadejuristen's availability on the streets of Vesterbro made it visible to the target group, and the visibility is essential to establish contact, map out legal problems, and provide the necessary aid and support. The professional training of Gadejuristen staff enables them to identify and address irregular processes, as in the case involving the appeal on the ruling that failed to provide reasons for the denial of in-patient treatment. Professional knowledge of the appeal system thus provides the organisation with the necessary tools to represent users and their interests.

Gadejuristen goes beyond traditional legal aid, as relationships with users often continue after the legal needs have been met. This contrasts with target groups' usual encounters with the welfare system, in which they often encounter a number of different caseworkers. In the case of some users, encounters with the welfare system and previous experiences with public authorities have led to scepticism or even mistrust of the system. If several caseworkers are involved in users' cases, it can be difficult to establish trust and ensure continuity in the process. Gadejuristen is aware of this and engages in legal work on the target group's terms by meeting people in the streets in outreach work, recognising their legal needs as well as their physical and social needs. It also creates a high degree of accessibility by making itself available in the streets as well as in the Gadejuristen office, and by offering them cell phones to enable contact (field notes). By adopting these extended legal practices, Gadejuristen is able to build up trust relationships with the target group, and dismantle some of the structures found in the welfare system, by ensuring that it is easy to access help from the organisation's staff. This help is often multifaceted, and includes extra-legal aid, such as providing cell phones, covering the costs of travel to meetings with, for example, caseworkers, and establishing networks aimed at empowering the target group to handle their everyday lives. An example of such networks is the Parents' Network, described above, which over the years has helped parents with current or past drug use to experience themselves as being less stigmatised and more recognised, and thereby empowered in their parenting skills. ${ }^{7}$ 
By making themselves available on the target group's terms, providing them with basic items, giving them a hot cup of coffee, and through dialogue recognising and appreciating their situation: in short by showing users that they are quite aware of their needs and way of life, Gadejuristen works to build up trust relations with socially marginalised people. Informality opens the way to conversation, and this enables the staff and volunteers to identify potential legal problems. By articulating an 'us and them' relationship; 'us' representing the users and the organisation, 'them' being the welfare system, the organisation shows awareness of the scepticism and lack of trust felt by users towards the welfare system. The 'us and them' discourse stresses that Gadejuristen and the users are on the same page, and that both parties consider the welfare system as the opponent. Thus, the organisation aligns with the target group, indicating solidarity and representation on the target group's own terms. The target group's experience of being listened to, recognised, and supported empowers them to handle their everyday lives.

\section{Navigating in the Welfare State: Gadejuristen as Mediators}

Gadejuristen plays a central role for the target group as it works to address the shortcomings of the welfare system, which at times is unable to include socially marginalised people (Frivilligrådet 2010, p. 5). A move in welfare administration towards management models inspired by new public management has led to political scepticism about the efficiency of the welfare state (Appel Nissen 2007, p. 64), which is reflected in a focus on the individual citizen as being solely responsible for their own situation (Bauman 2004, p. 66). This development has led to an increase in the demands made by the welfare system on citizens trying to access it: for example, the demand that people should change their circumstances to fit in with the functioning of the welfare system. The founder of Gadejuristen, Nanna Gotfredsen, experiences that the welfare system also has a 'you scratch my back and I'll scratch yours' mentality that is manifested when, for example, citizens have their benefits cut off, due to their failure to conform to the expectations of the system (Gotfredsen 2004, p. 9). Citizens who are able to conform to these expectations and demands are recognised in the welfare 
system as responsible and are included, while those who fail to 'follow the rules of the game' may lose benefits or be excluded from other rights (Knudsen and Åkerstrøm Andersen 2013, p. 71).

The organisation of the welfare system may, in some cases, create obstacles to socially marginalised people's access to rights; social workers are often specialised in narrow fields, such as housing, benefits, or health treatment, but rarely in all of them (Lied 2011, p. 286). Gadejuristen, however, provide legal aid that takes account of the complexity and multifaceted aspects of the target group's problems, and is therefore able to represent users in the welfare system and ensure their access to rights by means of legal strategies. Users may face difficulties in getting to welfare offices because of their, at times, chaotic lives. The way they live makes it difficult for them to meet the requirements of the system, such as going to the social service office and waiting in line to attend meetings with a caseworker. Gadejuristen knows by experience that users may have withdrawal symptoms, and/or are be unable to turn up for a scheduled appointment which limits their ability to fulfil the requirements of the welfare system. When this is the case, the consequence may be that social security benefits are no longer paid and that people are left with no money at all. According to Gadejuristen, this systemic structure does not fit well with the target group's ability to navigate within the welfare system.

As previous research on legal aid shows, accessing rights is not only a matter of knowing your rights, it is also a matter of having the resources to pursue them with the appropriate legal strategies. Both these elements are challenging for Gadejuristen's target group: they do not have the necessary knowledge of the law to formulate their health and social problems as legal problems, and because of their often chaotic lives, they do not have the resources to argue for their rights or pursue legal strategies (ibid., p. 173). In short, the target group often do not have the resources to name, blame, and claim, which are pivotal in a legal process. Naming your rights is the ability to identify your problem as being of a legal nature, blaming involves knowing who is responsible for fulfilling the rights, and claiming rights is the ability to articulate this in a legal framework (Felstiner et al. 1980). The inability to name, blame, and claim leaves the target group in a vulnerable position where they are unable to 
recognise and fight for their rights. This is described by the leader of Gadejuristen when she notes that many socially marginalised people do not know their own rights:

'Often they do not even have the resources to find out about their rights. And if you do not know your rights, of course you would not realise when you do not have them.' (Gotfredsen 2004, p. 1, our translation).

Gadejuristen works by establishing contacts with their target group, re-formulating everyday problems as legal problems, when appropriate, and representing users in encounters with the welfare system. For example, an everyday problem could translate into a legal problem if a user faced eviction because they had not been able to pay their rent due to lack of benefit payments. In such case, Gadejuristen would investigate the user's entitlement to benefits, why he/she has not received them, and then take on the case, with the user's consent. In order to establish contact with the target group, and help them obtain their rights, Gadejuristen must function on different structural terms than those of the welfare system and other legal aid institutions. If the organisation is to ensure that the users' rights are upheld, a high level of accessibility is required, together with detailed knowledge of the kind of problems most often faced by the target group.

Socially marginalised people seeking to access their rights often need to communicate with various parts of the welfare system, e.g., the health system, the local municipality, or administrative institutions. This requires an ability to navigate in these systems, which are often structured by and for those who are not socially marginalised. They need, for example, to be able to attend meetings arranged by a social worker or give satisfactory reasons for cancelling them. Such things can be challenging for Gadejuristen's users, as some have a limited ability to meet the requirements of the welfare system. This may lead to a labelling process where the target group is branded as 'not caring' or 'not trying' (Gotfredsen 2004, p. 7), though the issue is more often a matter of the discrepancy between the lifestyle of the target group and the structural functioning of the welfare system. 
Gadejuristen's role in such circumstances is to represent its users, help them enter the system through legal representation, remind about them about meetings with welfare system representatives, and cover the travel expenses for attending the meetings. Gadejuristen is able to represent users because it has a detailed knowledge of their circumstances, as well as the legal knowledge necessary to navigate the welfare system. This means they have easier access to relevant actors in the system, for example, they may have a telephone number to reach a caseworker after working hours, as well as resources to operate in the field, due to their knowledge of the way the welfare system functions, and of the rights of the user. Gadejuristen often represent users with the welfare system as the opponent in order to help them engage with welfare agencies in their terms (Gadejuristen 2011, p. 126). Gadejuristen considers this way of working for and with users a necessity in order to ensure their access to rights:

'We want to go to that level where people are not able to find their way to legal aid ... They [the target group] do not go to Stormgade, ${ }^{8}$ they cannot draw a number and wait for two hours, then they have withdrawal symptoms. You have to organise legal aid so that they are actually able to use it.' (Our translation)

Though the welfare system was set up to help socially marginalised people, some users are left behind because they lack the resources to navigate the system; they therefore rely on the aid from Gadejuristen. It is not just Gadejuristen's target group who sometimes lack sufficient legal knowledge; some caseworkers may lack the appropriate, up-to-date knowledge that is necessary to ensure users' access to rights (Lied 2011, p. 339). The lack of adequate legal knowledge leads to conflicts between Gadejuristen and caseworkers, who often have other considerations to bear in mind, such as budgetary constraints, that outweigh legal considerations (Rosholm 2009, p. 156; von Hielmcrone and Schultz 2007, p. 100) and a (too) great number of cases, which means that efficient casework is prioritised over detailed examination of each case (Wadskjær 2007, p. 91). 
Since most of the staff is trained jurists, Gadejuristen presents different arguments from arguments which the staff in the welfare system may put forward. Their professional legal background becomes evident when Gadejuristen acknowledges that representing the target group may be easier when talking to a lawyer in the administration; it speeds up the process, as there is a shared language and understanding of the law between legal professionals. The law is thus a means to further Gadejuristen's work and is applied when the organisation carries out legal policy work that aims to change unsound existing legislation and influence debates on new legislation (Gadejuristen 2011, p. 139). Legal knowledge puts Gadejuristen in a stronger position than their users, and many socially marginalised people find that it is not until Gadejuristen represents them that they are taken notice of by, for example, their caseworker. The difficulty of accessing justice means that the target group has to rely on the services of Gadejuristen. The unintended effect of this, however, is that users may feel offended by the fact that they are recognised when represented but undermined when they meet the social service system on their own (Lied 2011, p. 261).

The target group's difficulties in conforming to the ever-greater requirements and expectations of the welfare system leave them in a vulnerable position when trying to access and navigate the system. The systemic expectation of 'a willingness to change' may come up against their actual resources and living conditions. By working on their terms, Gadejuristen is able to represent the users' interests in encounters with the welfare system, and the detailed expertise of the organisation enhances its ability to address the shortcomings of the system, which may result from insufficient knowledge of the complexity of the lives of marginalised people.

The mismatch between how the welfare system functions and the life styles of the target group places Gadejuristen in a central role as mediators: staff and volunteers are able to reformulate what the users consider to be everyday problems into legal problems. Gadejuristen's expertise is necessary for the process of naming, claiming and blaming to be carried out. 


\section{Working on a Societal Level}

As mentioned, Gadejuristen provides legal aid on an individual level, in specific cases, and the organisation works at the societal level, as it represents the target group in public and in the media, arguing for improvements to their living conditions. Central to this is Gadejuristen's work at the policy level on reducing drug-related harms (Lied 2011, p. 276). Gadejuristen draws on experience in the field, and research in related areas, and has established an advisory board composed of researchers and experts in the field. It also involves the target group to gain an understanding of their needs from a bottom-up perspective. The organisation stresses the importance of an evidence-based approach, and the need for dialogue with the parties involved: the authorities as well as the people living on the streets, so that drug-related harms can be addressed from multiple angles. Contact with researchers, experts, and the target group thus enables Gadejuristen to formulate ways to improve the living conditions of society's most marginalised people from the starting point of research and social recognition.

Since the establishment of Gadejuristen in 1999, dialogue and lobbying initiated by Gadejuristen have led to changes in the political discourse on drugs and to a less repressive approach on the part of the police which has improved the lives of the target group. One improvement resulting from their lobbying and dialogue is the ending of the so-called ban zones. In the 1990s, Vesterbro was divided into ban zones where drug users, homeless people, and street sex workers were prohibited from gathering or walking, because their presence, according to the police, was upsetting for the residents and citizens of the locality. The introduction of the ban zones was not accompanied by the provision of an alternative place for the socially marginalised people to go, and the ban thus led to an increasing number of fines of between 600 and 1000 DKK [ $80 €$ and $135 €$ ] being imposed by the police, and then an increase in debt and imprisonment when they failed to pay the fines. Gadejuristen engaged in dialogue with the police, pointing out that the ban zones did not solve the problem, but merely caused stress among the organisation's target group and argued that the relationship between the police and the socially 
marginalised people was characterised by intolerance, fear, and repressive methods. Thus, Gadejuristen engaged with the police and argued on behalf of the target group that the ban zones did not result in nice, clean streets but damaged relations between the police and the target group. In 2012, the ban zones were dismantled as a result of the cooperation between the police and Gadejuristen.'

Gadejuristen does political legal work with the aim of improving the living conditions of the target group. This work focuses on two areas; first, it seeks to ensure that the practices of public authorities such as the police and caseworkers conform to existing legislation, and second, it seeks to change existing legislation when it is inadequate or unsound as regards the target group's needs (Gadejuristen 2011, p. 17).

The basis of Gadejuristen's political work is an evidence- and researchbased approach to understanding the situation of the target group. The organisation disseminates information through public meetings and the media, educates relevant actors, participates in the public debate through feature articles and discussion articles, and represents the causes of their users in public hearings (Lied 2011, p. 266). By disseminating information on a societal level, Gadejuristen hopes to make the lives of the people living on the streets better understood, and influence public and political opinion. The dissemination of information is thus prioritised by Gadejuristen as a way to nuance the debate and inspire political initiatives, which respect the autonomy of the target group and take their needs into account (Gadejuristen 2011, p. 33).

Gadejuristen frames itself as a Hard Core Harm Reducer, thus indicating that the organisation works to reduce drug-related harms. This is of relevance, as many of Gadejuristen users are involved in the drug scene and thus are affected by political initiatives and laws relating to that area (Gadejuristen 2011, p. 33). At the societal level, the legal approach of Gadejuristen is supplemented by research, cooperation with their advisory board, and dialogue with the actors involved-politicians, the target group, etc. The involvement of these different actors enables the organisation to take an evidence- and human rights-based approach to understand and articulate the needs of socially marginalised people, and disseminate information about them. Previous societal work has resulted in a less repressive approach to the target group on the part of the police 
to, and in political debate on drug use facilities. Moreover, by taking current research findings as its starting point, and drawing on the expertise of the advisory board, Gadejuristen is able to position itself as an authority in the field and thus well qualified to take part in discussions relating to harm reduction, socially marginalised people, and drug legislation.

Gadejuristen often invite politicians to participate in the street work to gain a better understanding of the target group. One of the main objectives in doing so is to address some current stereotypical political views of the drug scene and the needs of socially marginalised people. According to Gadejuristen, some politicians call the drug scene and drug use the friendly enemy. This means that the drug scene and drug use are portrayed as the reasons why the socially marginalised have problems handling everyday life and the welfare system. However, according to Gadejuristen, the target group often uses drugs as a means of coping with the actual problem, namely their complex living conditions (field notes). If politicians consider drugs to be the main concern, this may lead to unsound strategies that fail to consider the actual living conditions of socially marginalised people.

Working at the societal level with a focus on disseminating information, Gadejuristen has, to some extend, already improved the living conditions of the target group. This work continues with input from experts as well as users, in order to lobby for a better understanding of the situations of socially marginalised people and of how to address these within a sound legal and societal framework.

\section{The Street Lawyer Method}

Gadejuristen positions itself as a legal aid institution specifically targeting socially marginalised people. Making itself available on the terms of the target group and following an informal approach in street encounters are part of extended legal aid, and necessary to help a group of people in society who would otherwise face severe difficulties in navigating the welfare system (Lied 2011, p. 249). This characterises the Street Lawyer method, a term coined by Andenæs. He divides the method into three 
parts: a legal part, a professional part, and a practical part (Gadejuristen 2011, p. 132). The legal part of street lawyering consists of providing help through legal argumentation based on existing law. The professional part of street lawyering involves an interdisciplinarity that benefits the target group, by, for example, including specialised knowledge of the health issues of drug users. The practical part of street lawyering consists of practical support, such as covering users' transportation expenses and providing them with cell phones to enable them to make contact (ibid.). The three parts are seen in the following examples:

Based on their knowledge of the relevant law, Gadejuristen is able to re-formulate everyday problems as legal problems, thereby articulating the rights of the target group. Detailed knowledge of the drug scene enables the organisation to work at the policy level, and, for example, argue for the decriminalisation of drugs, as statistics show that this results in a reduction of drug-related harms. By way of practical support, Gadejuristen may cover the travel costs of getting to a meeting with a social worker, or provide cell phones in order to support users' access to social workers or other relevant actors.

As has been mentioned, Gadejuristen's objectives are to improve the circumstances of the target group, reduce drug-related harm, and ensure the group's access to rights. As shown above, a variety of methods is adopted by Gadejuristen to meet these objectives: dialogue, judicial policy, recognition, and informal encounters, and these distinguish Gadejuristen from traditional legal aid institutions and traditional lawyers (Lied 2011, p. 136). Nonetheless, the organisation also makes use of traditional legal methods. They only represent the user with her/his consent; when they represent their users their users' interests are the primary concern, and they make use of legal methods, identifying and applying relevant legal sources when arguing a user's case (Gadejuristen 2011, p. 134). The organisation can, however, be distinguished from traditional lawyers by the informal approach taken to (potential) users and the 'us and them' discourse that places the emphasis on equality and recognition in the relationship between staff and users.

The informal approach involves the speedy verbal exchange of information due to the need for rapid solutions in difficult situations. 
The welfare system is not flexible in the same way and lacks the ability to handle urgent cases: the informal approach that characterises extended legal aid enables Gadejuristen to identify potential legal problems and meet the, at times, urgent needs of the target group.

The working methods followed by Gadejuristen; the ability to respond quickly to cases thanks to informality and flexibility, the legal expertise, and practical support and empowerment of users, also help establish the trust between the organisation and its users that is crucial to mapping out problems and facilitating the legal process of identifying and enforcing rights. As mentioned, Gadejuristen adopts an 'us and them' discourse, identifying 'us' as the organisation and the user(s), and 'them' as the welfare system in all its various forms. The welfare system is often the adversary in the legal disputes dealt with by Gadejuristen (ibid., p. 89), and the 'us and them' discourse establishes the trust needed to address the users' complex problems (ibid., p. 286). Often the users' previous experiences of the welfare system have led to a feeling of lack of rights and lack of recognition. The social work done by the organisation helps establish the structures of trust that are necessary for socially marginalised people to become empowered and enabled to navigate the welfare system. Users' experiences of being rejected by the welfare system and of not knowing how to improve their situation, on the other hand, led to lack of trust in the welfare system and failure to improve their situations. Gadejuristen therefore strives to empower users by taking a recognitionbased approach, both verbally and physically. Greetings by name, hugs, and compliments are typical tools used to build up self-esteem, improve the users' self-image (ibid., p. 233), and help them handle their everyday lives.

Gadejuristen is able to meet its objectives by adopting the Street Lawyer method and by advocating for the rights of the target group at the policy level. The three different elements in the Street Lawyer method, together with the informality and flexibility characteristic of extended legal aid, constitute a holistic approach to the individual user. The focus on policy and social structures, on the other hand, is essential for Gadejuristen's ability to address issues at the societal level, and this policy work is part of extended legal aid, though it is not targeted at a specific 
user but at the life situations of the target group as a whole. The ability to act flexibly and informally ensures a degree of speediness, which is pivotal in some users' situations; a promptness that the structures of the welfare system cannot always offer. Gadejuristen is thus able to compensate for some of the system's shortcomings by using the Street Lawyer method, and providing extended legal aid, while also working at the policy level.

\section{Conclusion}

The examination of the Gadejuristen organisation, its work and the way current legislation and the structure and functioning of the welfare system affect the non-governmental organisation's target group, makes it evident that Gadejuristen plays an essential part in ensuring the target group's access to their rights. Though the welfare state was established to compensate for society's shortcomings, its structure, and the way it functions, do not support many socially marginalised people's ability to navigate in the welfare system. Gadejuristen works at the individual level, focusing on the user's needs, and at the societal level, lobbying for new policies and laws, and changes in the practices of public institutions, in order to increase the target group's access to rights and improve the situation of socially marginalised people.

The complexity of the users' problems calls for detailed expertise in various fields and a professional understanding of how to operate in these fields, in order to ensure the target groups' needs are met. By adopting the Street Lawyer method and thus making itself available on the terms of the target group, Gadejuristen is able to earn the trust of its users. The articulation of an 'us and them' relationship and an informal approach based on dialogue, recognition and appreciation facilitate contact between Gadejuristen and the target group, enabling the organisation to formulate and translate the everyday problems of the users as legal problems. Gadejuristen thus functions as a representative of its users when claiming their rights in the welfare system. That fact that the way 
the welfare system functions is often incompatible with the circumstances of the target group, and that some case workers lack legal knowledge, gives the organisation a pivotal role: Gadejuristen's expertise enables it to name, claim, and blame on behalf of its users.

Through lobbying and the dissemination of information at the societal level, Gadejuristen has to some extent managed to improve the living conditions of the target group. The organisation stresses the need for an evidence- and human rights-based approach, which is holistic in the sense that it involves all relevant actors. This approach is followed in the interests of achieving a better understanding of socially marginalised people's situations and how to address these. However, the societal and the individual levels are intertwined in the organisation's efforts to achieve its objective of improving the living conditions of the target group: the focus on the individual user enables Gadejuristen to represent her/his particular interests and thereby improve her/his situation.

As New Public Management has grown in the public sector, the everincreasing demands made by the welfare system on citizens have become part of everyday life. However, it may be difficult for the target group to satisfy these requirements which leaves them unable to navigate in the welfare system and in a vulnerable position as regards accessing their rights. The shortcomings of the welfare system are addressed by Gadejuristen through the organisation's ability to formulate users' problems as legal problems, thus using the law as the primary tool to access the welfare system.

\section{Notes}

1. http://gadejuristen.dk/om-gadejuristen

2. Gadejuristen refers to the people making use of their services as 'users'. The term is therefore applied throughout the chapter.

3. http://gadejuristen.dk/netv\%C3\%A6rks-og-gadeplansprojektet

4. Regulations of Gadejuristen, section 8.

5. http://gadejuristen.dk/udg\%C3\%A5ende-retshj\%C3\%A6lp

6. http://gadejuristen.dk/for\%C3\%A6ldre-m\%C3\%B8dregruppe

7. http://gadejuristen.dk/for\%C3\%A6ldre-m\%C3\%B8dregruppe 
8. Stormgade is the address of the office of Copenhagen Legal Aid, which offers free legal aid to citizens who drop by or telephone them (see Chap. 5).

9. http://www.gadejuristen.dk/forbudszonerne-er-nu-fortid

\section{Bibliography}

Appel Nissen, M. (2007). Magt og forandring i socialt arbejde. In M. Appel Nissen, K. Pringle, \& L. Uggerhøj (Eds.), Magt og forandring i socialt arbejde. København: Akademisk Forlag.

Bauman, Z. (2004). Forspildte liv. København: Hans Reitzels Forlag.

Civilstyrelsen. (2015). Beretning om tilskud til retshjalpsinstitutioner. Available via: http://www.civilstyrelsen.dk/ /media/Fri\%20Proces/Beretning_2015. ashx

Felstiner, W. L. F., Abel, R. L., \& Sarat, A. (1980). The emergence and transformation of disputes: Naming, blaming, claiming. Law \& Society Review, 15(3/4), 631-654.

Frivilligrådet. (2010). Et starkt velfardssamfund skal skabes sammen med borgerne! Reformoplæg fra Frivilligrådet. Available via: http://www.frivilligraadet.dk/ sites/default/files/udgivelser/reformoplaeg_0.pdf

Gadejuristen. (2011). Dokumentationsrapport. Available via: http://gadejuristen. $\mathrm{dk} /$ sites/default/files/Gadejuristen $\% 20$ Unders\%C3\%B8gelse $\% 20 \mathrm{af} \% 20$ udsattes\%20retshj\%C3\%A6lpsbehov\%20V5\%2016\%20nov\%202011_0. pdf

Gotfredsen, N. (2004). Gadejura. En nødløsning i en undtagelsestilstand. Tid til respekt. Dalager, S. and Jørgensen, P. S. (eds.) Socialpolitisk Forlag.

Knudsen, H., \& Åkerstrøm Andersen, N. (2013). Hyperansvar: når personligt ansvar gøres til genstand for styring. Dansk Sociologi, 4/24.

Lied, C. (2011). Irriterende til stede. Om gatejurister i Oslo og København. Olso: Det juridiske fakultet.

Rosholm, M. (2009). Økonomiske mekanismers betydning for marginaliseringsprocesser på arbejdsmarkedet. In J. Elm Larsen \& N. Mortensen (Eds.), Udenfor eller Indenfor. Sociale marginaliseringsprocessers mangfoldighed. København: Hans Reitzels Forlag. 
von Hielmcrone, N., \& Schultz, T. (2007). Større retssikkerhed i det sociale arbejde? In A. Nielsen, M. Appel, K. Pringle, \& L. Uggerhøj (Eds.), Magt og forandring $i$ socialt arbejde. København: Akademisk Forlag.

Wadskjær, H. (2007). Den sociale hjælpefunktion. In M. Appel Nielsen, K. Pringle, \& L. Uggerhøj (Eds.), Magt og forandring $i$ socialt arbejde. København: Akademisk Forlag.

Open Access This chapter is distributed under the terms of the Creative Commons Attribution 4.0 International License (http://creativecommons.org/ licenses/by/4.0/), which permits use, duplication, adaptation, distribution, and reproduction in any medium or format, as long as you give appropriate credit to the original author(s) and the source, a link is provided to the Creative Commons license, and any changes made are indicated.

The images or other third party material in this book are included in the work's Creative Commons license, unless indicated otherwise in the credit line; if such material is not included in the work's Creative Commons license and the respective action is not permitted by statutory regulation, users will need to obtain permission from the license holder to duplicate, adapt or reproduce the material.

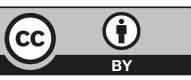

